\title{
CELLULÁRIS STRUKTÚRÁK TOPOLÓGIAI JELLEMZÉSE
}

\section{ON THE TOPOLOGICAL CHARACTERIZATION OF CELLULAR STRUCTURES}

\author{
Réti Tamás ${ }^{1}$, Réger Mihály ${ }^{2}$, Nagyné Halász Erzsébet ${ }^{3}$ \\ I'Óbudai Egyetem, Bánki Donát Gépész és Biztonságtechnikai Mérnöki Kar, Anyag- \\ tudományi és Gyártástechnológiai Intézet 1086 Budapest, Népszinház utca 8. Tele- \\ fon / Fax: +36-1-666-5386, levelezésicim,reti.tamas@bgk.uni-obuda.hu \\ ${ }^{2}$ Óbudai Egyetem, Bánki Donát Gépész és Biztonságtechnikai Mérnöki Kar, Anyag- \\ tudományi és Gyártástechnológiai Intézet 1086 Budapest, Népszinház utca 8. Tele- \\ fon / Fax: +36-1-666-5386, levelezési cím,reger.mihaly@bgk.uni-obuda.hu \\ ${ }^{3}$ Óbudai Egyetem, Bánki Donát Gépész és Biztonságtechnikai Mérnöki Kar, Anyag- \\ tudományi és Gyártástechnológiai Intézet 1086 Budapest, Népszínház utca 8. Tele- \\ fon / Fax: +36-1-666-5386, levelezési cím,nagyne.halasz@bgk.uni-obuda.hu
}

\begin{abstract}
For the global structural characterization of cellular systems a novel method is suggested. The new approach is based on the following graph-theoretical concept. As it is known a two- or threedimensional cellular system composed of polygons or polyhedra can be represented by a finite or an infinite graph. Considering the corresponding dual graph, an appropriately defined topological descriptor is constructed, which can be applicable for the quantitative structural characterization of various cellular systems. Tests performed on the graphs of fullerene isomers demonstate that the novel topological descriptor is efficiently used for the preselection of most stable fullerene isomers.

Keywords: cellular systems, infinite graph fullerene isomer.

\section{Összefoglalás}

A celluláris anyagok strukturális jellemzésére egy új típusú eljárást ismertetünk. A módszer egy gráfelméleti koncepción alapul: Mint ismertes, a poligonokból illetve poliéderekből álló 2-illetve 3dimenzós celluláris rendszer egy véges vagy végtelen gráffal reprezentálható. Ennek duális gráfját képezve, egy célszerúen definiált topológiai deszkriptor konstruálható, amely alkalmas különféle celluláris rendszerek kvantitatív strukturális jellemzésére. Fullerén izomerek gráfjai felhasználásával végzett tesztekkel demonstráltuk, hogy a javasolt új topológiai deszkriptor hatékonyan alkalmazható a leginkább stabilnak tekinthető izomerek kiválasztására.
\end{abstract}

Kulcsszavak: celluláris anyagok, végtelen gráf, fullerén izomer. 


\section{Bevezetés}

A celluláris rendszereket, más néven sejtrendszereket elterjedten használják számos anyag mikroszerkezeti modellezésére, ezek közé sorolható a polikristályos ötvözetek, a fémhabok, egyes nonoszerkezetek, fullerének. Geometriai szempontból a 2- és 3-dimenziós sejtrendszereket poligonok illetve poliéderek alkotják [1,2,3]. Ezek kvantitatív morfológiai jellemzése, osztályozása napjainkban is változatlanul a kutatás homlokterében van. A következőkben olyan új típusú globális topológiai alaktényezőt definiálunk, amely egyszerü módon, közvetlenül származtatható a celluláris rendszer gráfjának, illetve ez utóbbi duális gráfjának ismeretében.

A celluláris anyagok vizsgálatára különféle geometriai modellek használatosak, ezek legismertebb és legfontosabb változatai a következők $[1,2,3]$ :

- Véges számú különbözö típusú, térkitöltő poliéderből konstruált 3dimenziós periódikus sejtrendszerek [1], ezekre tipikus példa az egyfázisú polikristályos ötvözetek mikroszerkezete,

- Azon 2- és 3-dimenziós random sejtrendszerek, amelyek származtatásához alapul többnyire a sík illetve a tér Voronoi-tesszellációja vagy ennek valamilyen általánosított változata szolgál,

- Véges számú különböző típusú, poligonokból illetve térkitöltő poliéderből, konstruált 2- illetve 3-dimenziós kvázi-periódikus sejtrendszerek [3].

Véges kiterjedésü zárt felületet (gömb, tórusz) hézagmentesen lefedő, véges számú különböző típusú poligon alkotta sejtrendszerek (ilyenek például a fullerének [4]).

\section{2. Új típusú globális topológiai deszkriptor származtatási elve}

A celluláris rendszer strukturális jellemzésére javasolt $\Psi$ globális topológiai deszkriptor származtatása az alább részletezett koncepción alapul: Tekintsük a sejtrendszer egy tetszőleges $A$ sejtjét, amelyet kétdimenziós rendszerben egy poligon, 3dimenziósrendszerben egy poliéder reprezentál. Az egyszerüség kedvéért, tételezzük fel, hogy a sejtek konvex poligonok illetve konvex poliéderek.

Jelölje $C_{2}(A)$ az $A$ poligonsejt élszomszédos környezetét, vagyis azon poligonok halmazát, amelyeknek az A sejttel közös éle van, illetve jelölje $C_{3}(A)$ az $\mathrm{A}$ polidédersejt lapszomszédos környezetét, vagyis azon poliéderek halmazát, amelyeknek az $A$ sejttel közös lapja van. A $\Psi$ topológiai deszkriptor definiálásához az élszomszédos illetve a lapszomszédos sejtek geometriai paraméterei, nevezetesen a szomszédos sejtek élszámai illetve lapszámai szolgálnak kiindulási alapul.

Amennyiben a sejtrendszert az $\left\{A_{l}\right.$, $\left.A_{2}, \ldots A_{i}, . . A_{N}\right\}$ sejtek $N$ elemü halmaza alkotja, akkor minden egyes 2- illetve 3dimenziós $A_{i}$ sejthez, hozzárendelhető egy $U\left(A_{i}\right)$ vektor, amely a szomszédos sejtek élilletve lapszám szerinti eloszlását egyértelműen jellemzi. A $\Psi$ globális topológiai deszkriptort az $U\left(A_{i}\right)$ vektor-komponensek alkalmasan definiált függvényeként származtatjuk.

Tekintve, hogy egy tetszőleges $A$ sejt $C_{2}(A)$ illetve $C_{3}(A)$ környezetében a szomszédos sejtek sokféle konfigurációban fordulhatnak elö, ezért várható, hogy a különféle sejtrendszerek egymástól eltérő struktúrája kielégítő módon jellemezhető az él- illetve lapszomszédos sejtek lehetséges kombinációinak ismeretében.

Példaként tekintsük a fullerén típusú sejtrendszereket [4]. A fullerének karbon bázisú molekulák, olyan speciális sejtrend- 
szereknek tekinthetök, amelyek geometriai szempontból ötszögek és hatszögek által határolt egyszerü (trivalens) poliéderekkel modellezhetők. Következésképpen a sejtek 5- illetve 6-szögek, és a poliéder minden egyes csúcsában pontosan 3 él találkozik. Egy n csúcsszámú $C_{n}$ fullerénnek, (ahol $n$ $\geq 20$, és $n \neq 22$ ) pontosan $F_{5}=12$ számú ötszöglapja és $F_{6}=(n / 2)$ - 10 számú hatszöglapja van. Azonos csúcsszámú fullerénnek több, szerkezetileg különböző izomerje létezhet, az izomerek száma drasztikusan növekszik a csúcsszám növekedésével. Amennyiben

$n=60$, a $C_{60}$ típusú fullerén izomereinek száma 1812, ezek mindegyikét egymástól különböző, nem-izomorf gráfok reprezentálják. A globális topológiai deszkriptor $(\Psi)$ definiálásához illetve számításához célszerü az izomerek gráfjainak duálisát használni. A duális gráfok háromszögek alkotta síkbeli gráfok, közös jellemzőjük, hogy egy duális gráfban a csúcsok fokszáma 5 illetve 6 . Jelölje egy $C_{n}$ fullerén-gráf duális gráfját $C_{\text {dual }}(n)$, ez esetben a $C_{\text {dual }}(n)$ duális gráf pontosan 12 darab ötödfokú csúcsot és $n / 2$ 10 darab hatodfokú csúcsot tartalmaz. A fullerén izomerek strukturális jellemzésére hivatott $\Psi$ deszkriptort a különböző élszomszédos környezetek figyelembe vételével, az alábbi képlettel definiáltuk:

$$
\Psi=\Psi\left(C_{n}\right)=\sum_{j=0}^{5} n_{5, j} D_{5, j}^{2}+\sum_{j 70}^{6} n_{6, j} D_{6, j}^{2}
$$

A fenti formulában $\mathrm{n}_{5, \mathrm{j}}$ és $\mathrm{n}_{6, \mathrm{j}} \quad \mathrm{az}$ élszomszédos $C(5, j)$ illetve $C(6, j)$ poligonkonfigurációk száma, $D_{k j}$ pozitív egész számok pedig az ún. konfigurációs paraméterek. A $D_{k, j}$ paraméterek aktuális értéke megegyezik az adott k-oldalszámú sejttel élszomszédos poligonok (5- illetve 6szögek) oldalszámaink összegével. Ez utóbbiak definíció szerint az alábbi formulákkal számíthatók: $D_{5, j}=30-j$, illetve $D_{6, j}=$ $30+j$ (lásd az 1. táblázat adatait).
1. táblázat. Élszomszédos konfigurációs jellemzök fullerénekben

\begin{tabular}{|c|c|c|c|c|}
\hline \multicolumn{5}{|c|}{ Élszomszédos konfigurációk paraméterei } \\
\hline $\mathrm{k}$ & $\mathrm{j}$ & $\mathrm{C}(\mathrm{k}, \mathrm{j})$ & $\mathrm{D}_{\mathrm{k}, \mathrm{j}}$ & $\mathrm{n}_{\mathrm{k}, \mathrm{j}}$ \\
\hline \multirow{6}{*}{5} & 0 & $0 \times 5+5 \times 6$ & $\mathrm{D}_{5,0}=30$ & $\mathrm{n}_{5,0}$ \\
\cline { 2 - 5 } & 1 & $1 \times 5+4 \times 6$ & $\mathrm{D}_{5,1}=29$ & $\mathrm{n}_{5,1}$ \\
\cline { 2 - 5 } & 2 & $2 \times 5+3 \times 6$ & $\mathrm{D}_{5,2}=28$ & $\mathrm{n}_{5,2}$ \\
\cline { 2 - 5 } & 3 & $3 \times 5+2 \times 6$ & $\mathrm{D}_{5,3}=27$ & $\mathrm{n}_{5,3}$ \\
\cline { 2 - 5 } & 4 & $4 \times 5+1 \times 6$ & $\mathrm{D}_{5,4}=26$ & $\mathrm{n}_{5,4}$ \\
\hline & 5 & $5 \times 5+0 \times 6$ & $\mathrm{D}_{5,5}=30$ & $\mathrm{n}_{5,5}$ \\
\hline \multirow{6}{*}{6} & 0 & $0 \times 6+6 \times 5$ & $\mathrm{D}_{6,0}=30$ & $\mathrm{n}_{6,0}$ \\
\hline & 1 & $1 \times 6+5 \times 5$ & $\mathrm{D}_{6,1}=31$ & $\mathrm{n}_{6,1}$ \\
\hline & 2 & $2 \times 6+4 \times 5$ & $\mathrm{D}_{6,2}=32$ & $\mathrm{n}_{6,2}$ \\
\hline & 3 & $3 \times 6+3 \times 5$ & $\mathrm{D}_{6,3}=33$ & $\mathrm{n}_{6,3}$ \\
\hline & 4 & $4 \times 6+2 \times 5$ & $\mathrm{D}_{6,4}=34$ & $\mathrm{n}_{6,4}$ \\
\hline & 5 & $5 \times 6+1 \times 5$ & $\mathrm{D}_{6,5}=35$ & $\mathrm{n}_{6,5}$ \\
\hline & 6 & $6 \times 6+0 \times 5$ & $\mathrm{D}_{6,6}=36$ & $\mathrm{n}_{6,6}$ \\
\hline
\end{tabular}

A fenti meggondolásokból adódik, hogy $C_{n}$ fullerénre érvényes az

$$
\mathrm{F}_{5}=\mathrm{n}_{5,0}+\mathrm{n}_{5,1}+\mathrm{n}_{5,2}+\mathrm{n}_{5,3}+\mathrm{n}_{5,4}+\mathrm{n}_{5,5}=12 \text {, }
$$

illetve az

$$
\begin{gathered}
F_{6}=n_{6,0}+n_{6,1}+n_{6,2}+n_{6,3}+n_{6,4}+n_{6,5}+n_{6,6}= \\
=k / 2-10
\end{gathered}
$$

egyenlőség.

Amint az 1. táblázat adataiból kitünik, az 5 és 6 szögek élszomszédos környezeteit reprezentáló $C(k, j)$ sejtkonfigurációk száma éppen 13. Ezekhez pontosan 12 különbözö $D_{k, j}$ paraméterérték tartozik. Ésszerü az feltételezés, hogy az ily módon definiált $\Psi$ globális deszkriptor nagy valószínűséggel erősen szelektív, azaz jelentős mérvü diszkriminációs képességgel rendelkezik.

\section{Alkalmazási példa: fullerén tí- pusú sejtrendszerek topológiai jellemzése}

Az előzőkben definiált $\Psi$ globális topológiai deszkriptor gyakorlati alkalmazási lehetőségeinek tesztelésére $\mathrm{C}_{36}$ fullerénizomerekre vonatkozóan végeztünk elözetes vizsgálatokat. Elemeztük az egyes izomerek stabilitását minősítő En energetikai paraméter valamint a $\Psi$ deszkriptor közötti kapcso- 
latot. $\mathrm{Az} E n(\mathrm{eV})$ energetikai paraméter számítása a Density Functional TightBinding (DFTB) módszerrel történt [5]. Mint ismeretes, minél kisebb az En energetikai paraméter értéke annál stabilabbnak tekintendő a hozzá tartozó izomer.

Pontosan 15 izomerje létezik a $\mathrm{C}_{36}$ típusú fulleréneknek. Közülük az energetikai számítások szerint a legstabilabb a C36:14 izomer, ezt követik sorrendben a C36:15, C36:12, C36:9 majd a C36:11 izomerek. A legkevésbé stabilnak a C36:2 izomer tekinthetö. Ezen izomerekre vonatkozóan a globális deszkriptor számított értékei a következők voltak:

$$
\begin{aligned}
& \Psi(C 36: 14)=17348, \\
& \Psi(C 36: 15)=17352, \\
& \Psi(C 36: 12)=17364, \\
& \Psi(C 36: 9)=17364, \\
& \Psi(C 36: 11)=17368,
\end{aligned}
$$

illetve

$$
\Psi(C 36: 2)=17468 .
$$

Mint megállapítható, a $\Psi$ globális deszkriptor és az En energetikai jellemző között szoros korrelációs kapcsolat áll fenn: nevezetesen minél kisebb En értéke (azaz minél stabilabb egy fullerén-izomer) annál kisebb a $\Psi$ deszkriptor értéke. Ebből arra következtethetünk, hogy a $\Psi$ deszkriptor eredményesen alkalmazható a fullerénizomerek strukturális jellemzésére, valamint stabilitásuk predikciójára.

\section{Szakirodalmi hivatkozások}

[1] Williams, R.: The Geometrical Foundation of Natural Structure: A Source of Book of Design, New York, Dove, 1979.

[2] Reti, T., Böröczky, K.J.: Topological Characterization of Cellular Structures, Acta Polytechnica Hungarica, 1 (2004) p. 59-85.

[3] Böröczky, K.J., Réti, T., Wintsche, G.: On the combinatorial characterization of quasichrystals, Journal of Geometry and Physics, 57 (2006) 39-52.

[4] Fowler, P.W., Manolopoulos, D.E.: An Atlas of Fullerenes, Calendron Press, Oxford, 1995.

[5] Porezag, D., et al., Construction of tightbinding-like potentials on the basis of density-functional theory: Application to carbon, Phys. Rev. B51, (1995) 12947-12957. 